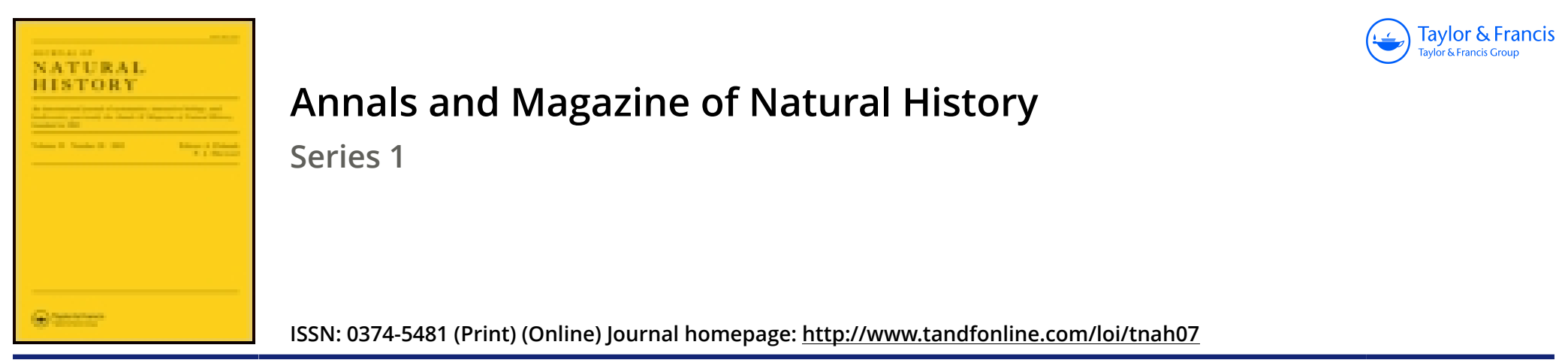

\title{
Ciconia Alba
}

\section{J.R. Harvey M.D.}

To cite this article: J.R. Harvey M.D. (1846) Ciconia Alba, Annals and Magazine of Natural History, 18:116, 70-70, DOI: 10.1080/037454809494396

To link to this article: http://dx.doi.org/10.1080/037454809494396

曲 Published online: 10 Dec 2009.

Submit your article to this journal 중

Q View related articles $₫$ 
it, the fish descends in the water; it rises arain by relaxing the muscles which had served to compress the bladder. Moreover, the fish may remain at the bottom of the water, by the very fact of the pressure of the column of water on the air contained in the bladder.

By compressing more or less the posterior portion or the anterior portion of the bladder, the animal is able to render the anterior half or the posterior half of its body lighter at will; it can also take an oblique position, which allows a movement of rising or of descending in the water. The arrangement of the natatory bladder in some fishes might favour this action. 'The Cyprinoids and the Characi have two bladders, one before the other, and communicating together by a narrow tube. The anterior bladder is very elastic, whereas the posterior one is very slightly so ; and in proportion as the fish rises in the water, the anterior bladder, which is the most elastic, must considerably increase in volume, and thus keep the head of the animal up, whilst the contrary must be the case when the fish descends.-Miiller's Archiv, 1845, p. 456.

CICONIA ALBA.

A fine specimen of the Stork (Ciconia alba, Ray) was shot a few weeks since near Fermoy in the county of Cork. It appears that three indiriduals were seen, but this only was procured. It is now in the possession of the Rev. Mr. Bradshaw of this city. I am not aware of any authentic record of the species having been met with in Ireland before. J. R. HarveY, M.D.

Cork, June 17, 1846.

\section{Limbryogeny of the Ornithomyice. By M. Blanchand.}

'The Ornithomyia, or Pupipares of Latreille, are parasitic on mammiferæ and birds. They have for a long time attracted the attention of entomologists, by an exceptional mode of reproduction which distinguishes them from all other insects. 'They do not deposit eggs, nor even larvæ, like some other Diptera, but nymphs, the external envelope of which hardens in contact with the air, and from which issues a few days afterwards the perfect insect.

Anatomists are not agreed as to whether the embryos pass, in the maternal ovary, through the ordinary phases of the metamorphoses of insects. Latreille supposed that the nymphs are at first under the form of eggs, and pass their life as larvæ within the body of the nother. Leon Dufour, from examinations of the Hippoboscus of the horse, and the Melophagus of sheep, thinks, on the contrary, that the embryos of the Ornithomyia are never comparable to eggs or to larræ.

M. Blanchard has examined the Leptotena of the stag, and he has found, in the uvary of the females, embryos which completely resemble the lurva of the Diptera, by their soft teguments, their corneous head, their two loug tracheæ, and their nervous system collected in the anterior part of the body. 'The only important difference 